Dorit Gottesfeld

Ronen Yitzhak

\title{
The Unknown Aspect of Israeli-Jordanian Relations from 1948 to 1967
}

The Mandelbaum Gate, which marked the border between Jerusalem's two zones from 1948 to 1967, and which was the only open crossing between Israel and Jordan, was a quiet, peaceful haven in an otherwise tumultuous region. The checkpoint was the only place in which a relative normalization existed between two states which had failed to reach a peace agreement in 1950 . The checkpoint had operated effectively over the years, with almost no significant disputes which might have caused some disruption.

In this paper, we intend to shed light on this closed and unique area and to argue that although it did not reflect its surroundings (i.e. war between Jordan and Israel), it constituted an altogether different face of Israeli-Jordanian relations during the period under discussion.

The paper will outline Israeli-Jordanian relations between 1948 and 1967 from a different and unique viewpoint which has not, as yet, been explored. Initially, it will provide an historical review of the battles of Jerusalem in the 1948 war, after which, it will deal with the establishment of the checkpoint and describe the normalization that came to exist there. The paper will also focus on the Mandelbaum Gate and how it was reflected in historical archives and also in Palestinian literature from the period.

\section{Historical Background: The Battles of Jerusalem in the 1948 War}

On 14 May 1948, towards the end of the British Mandate in Palestine, the Haganah, the main military force of the Jews during the British Mandate (1920-1948), launched Operation Kilshon (Pitchfork), in an attempt to achieve territorial continuity in Jerusalem ${ }^{1}$. The operation was part of a larger plan devised by the Jews, namely, Operation D, which aimed to take control of as many territories as possible in Palestine prior to the establishment of a Jewish state upon the end of the Mandate ${ }^{2}$. Among the territories occupied by the Jews in April 1948 were mixed cities in which Jews and Arabs lived together, in Tiberias, Haifa, Jaffa and Safed ${ }^{3}$.

\footnotetext{
${ }^{1}$ Israel Defense Forces (IDF) Archives 33/500/48: Advance warning of Operation Kilshon, 14 May 1948.

${ }^{2}$ For the order of Plan Dalet see IDF Archives 93/6127/49, 10 March 1948.

${ }^{3}$ Tiberias was the first to be conquered by the Jews on 18 April 1948, then Haifa on 21 April, Jaffa on 30 April and Safed was conquered on 11 May 1948.
} 
During operation Kilshon, which was implemented in three areas in Jerusalem, North, Central and South, the Jews managed to occupy several Arab neighborhoods (including Sheikh Jarrah, Talbiyya and Abu Tur) and to take control of the American and German colonies (established at the end of the 19th century in Jerusalem) as well as the British military camps. They also occupied both strategic roads and establishments in the city, such as the postal service, the telegraph, the train stations and police stations. On 14 May, the forces reported to the Haganah headquarters that "The Arab enemy's resistance is very weak".

The Jews' activities were a cause for deep concern for the Arabs in Jerusalem, as they believed that the Jews were also planning to take the Temple Mount (al-Aqsa), although this was not in fact part of the Jewish military operation $^{5}$. However, when the Jewish fighters entered the Jewish Quarter of the Old City, it caused great concern amongst the Arabs who called upon their leaders for help ${ }^{6}$.

The first Arab leader who came to the aid of the Arabs in Jerusalem at this time was King Abdullah of Jordan. It seems that this was as a result of the political pressure of the Arab leaders, especially the Arab League General Secretary, Abd al-Rahman Azzam who directed King Abdullah to intervene in Jerusalem. The Arab newspapers, also put pressure on Abdullah to intervene by highlighting the fact that the Jordanian soldiers in Palestine had not come to the aid of the Arabs in Jerusalem. Consequently, King Abdullah did in fact intervene in Jerusalem, however the main reason for this was in order to realize his political ambitions there ${ }^{7}$. Throughout the Mandate period (1920-1948), the British prevented him from achieving his goals in Jerusalem and accordingly, when the British pulled out, leaving the Arabs in distress, Abdullah saw this as a good opportunity to intervene. Abdullah had intended to take control, despite the fact that Jerusalem had been established as an international zone by the UN partition resolution.

However, King Abdullah's plans were thwarted by the commander of the Jordanian army who was a British officer named General John Bagot Glubb (Glubb Pasha). Glubb Pasha was opposed to entering Jerusalem because the UN partition resolution of November 1947 stated that the area was international territory. He acted in accordance with the British interest and Abdullah was

\footnotetext{
${ }^{4}$ IDF Archives 2/464/1954: From "Etzioni” to Yadin 14 May 1948.

${ }^{5}$ The al-Aqsa Mosque on the Temple Mount is considered by Muslims to be the third most important place in Islam after the two mosques in Mecca and Medina (in Saudi Arabia. IDF Archives, Advance warning of Operation Kilshon 14 May 1948).

${ }^{6}$ National Archives (London), FO 371/68829: Amman to Foreign Office, 19 May 1948.

${ }^{7}$ According to Arab sources, Arab delegations headed by the secretary of the Arab League arrived in Amman on 16 May 1948 to meet King Abdullah. A. al-Arif, Nakbat Filastin wal-Fardus al-Mafqud, Amman 1956, p. 451.
} 
therefore only allowed to enter those areas allocated to the Arabs (i.e., the West Bank) by the UN partition resolution ${ }^{8}$.

In light of the above, according to the Jordanian historian Suleiman Musa, King Abdullah instead ordered an Arab officer, Abdullah al-Tall, to enter Jerusalem with his forces in an attempt to save it from the Jews ${ }^{9}$. Abdullah al-Tall was chosen for the task as he was stationed in Jericho only 17 kilometers from Jerusalem and accordingly he was the Arab officer closest to the city. On 18 May, al-Tall, along with his soldiers, invaded the Old City and after ten days of fighting (on 28 May), he conquered the Jewish Quarter and took about 290 Jews as prisoners of war $^{10}$.

In addition to the battles in the Old City and in southern Jerusalem (Ramat Rachel, 24-25 May), battles also took place in northern Jerusalem. On 19 May, Jordanian soldiers, who came from Ramallah to Shu'afat, in north Jerusalem, entered Sheikh Jarrah and captured it from the Jews, who had held it since the Haganah forces conquered it during operation Kilshon. The infantry soldiers of the Jordanian army had attempted to advance towards the nearby Jewish neighborhoods, but they were held back, while armored cars moved towards Damascus Gate, joining the Jordanian forces which had fought in the Old City ${ }^{11}$.

The occupation of Sheikh Jarrah was important to the Jordanian army because it cut off Mount Scopus which housed two Jewish institutions which had been established there in 1920s and 1930s, namely, the Hebrew University and the Hadassah Hospital from New Jerusalem (Hebrew Jerusalem), keeping them both under siege. Moreover, the conquest also enabled the Jordanian army to advance towards the Jewish neighborhoods close to Sheikh Jarrah (Hebrew Jerusalem) and occupy them. Indeed, the following day (20 May) the Jordanian soldiers attempted to break through the Jewish neighborhoods, but were defeated by the Haganah force ${ }^{12}$. One of the most important Israeli positions in this area which played a crucial role in the removal of the Jordanians from the Jewish neighborhoods of Jerusalem was the Mandelbaum House.

\section{The Establishment of the Mandelbaum Gate}

The Mandelbaum house was named after Simcha Mandelbaum, a religious Jew who had immigrated to Palestine from Poland in 1882. At first, he lived in the Old City, but in 1929 he moved to this house which he built near Sheikh Jarrah and the ultra-Orthodox neighborhoods. After he built the house, it turned

${ }^{8}$ J.B. Glubb, A Soldier with the Arabs, London 1957, p. 108.

${ }^{9}$ S. Musa, Ayyam La Tunsa: al-Urdun fi Harb 1948, Amman 1982, p. 127.

${ }^{10}$ IDF Archives 1/464/54: From "Etzioni” to Yadin, 18.05.1948; IDF Archives, 39/500/48: Surrender of the Jewish Quarter, 28.05.1948; al-Arif, Nakbat Filastin, p. 456; A. al-Tall, Karithat Filastin, Mudhakirat Abdullah al-Tall Qa'id Ma'rakat al-Quds, Cairo 1959, pp. 106-107.

${ }^{11}$ J.B. Glubb, A Soldier with the Arabs..., p. 111; S. Musa, Ayyam La Tunsa..., p. 179.

${ }^{12}$ A. al-Tall, Karithat Filastin..., p. 158. 
out that the land belonged to the Islamic Waqf, and therefore the Moslims refused to sell any more land in this area to Jews. Thus, the house remained on the front line of the Jewish neighborhoods, in the heart of an Arab population, and consequently it became an important strategic asset for the Haganah. When the 1948 War broke out, the Mandelbaum family transferred the building to the Haganah, so that it could serve as its headquarters ${ }^{13}$.

During the "Ten Days" battles in July 1948 (9-18 July 1948), the Jordanian army renewed its attempt to break into the Jewish neighborhoods through the Mandelbaum House, but it was repelled and finally, on 19 July, at the end of the battles, it succeeded in blowing up the house, killing many Israeli soldiers ${ }^{14}$. Nevertheless, because of the strategic location of the house, its remains became a meeting place between The Israel Defense Force (IDF) commanders and the Jordanian army during the war, as explained below.

Mandelbaum's first role in the relations between the two countries was to send out convoys every two weeks to the demilitarized enclave of Mount Scopus. The agreement between Israel and Jordan, which was signed on 7 July 1948, stated that the areas of Hadassah Hospital, the Hebrew University, Augusta Victoria and the Arab village of Isawiyya would all be considered demilitarized, and that the United Nations would assume responsibility for them. According to the agreement, the armed forces (both Jews and the Arabs) had to withdraw from these areas in order to be replaced by Jewish civil police and an Arab police force that would be replaced every two weeks ${ }^{15}$. Thus, Israeli convoys left the Mandelbaum Gate in the direction of Mount Scopus every two weeks, under the supervision of the United Nations and Jordanian soldiers ${ }^{16}$.

The agreement expressed the desire of both sides to remove Mount Scopus from the cycle of hostilities. This was the first such agreement on the removal of areas from the fighting, that had been signed during the war between Israel and Jordan. It illustrated the sentiment that it was possible for the two countries to reach understandings in the future. This agreement also encouraged them to sign an additional agreement two weeks later, on 21 July, in which the parties undertook to maintain the cease-fire lines between them within Jerusalem as part of the Israeli-Jordanian policy of avoiding war between themselves. The agreements were finalized in meetings of the Zionist leaders with King

${ }^{13} \mathrm{~K}$. Cohen-Hattab, The Border as Bridge: An Israeli Perspective on the Mandelbaum Gate in Divided Jerusalem (1948-1967), "Middle Eastern Studies" 2017, Vol. 53, Issue 6, pp. 880-881.

${ }^{14}$ S. Musa, Ayyam La Tunsa..., p. 442; A. al-Tall, Karithat Filastin..., p. 213.

${ }^{15}$ On the agreement on the demilitarization of Mount Scopus see Israel State Archives (ISA) $130.16 / 19$ and a letter from the government legal advisor to the foreign minister of 2 September 1948 which clarifies the legal status of both institutions in the same file.

${ }^{16} \mathrm{~K}$. Cohen-Hattab, The Border as Bridge..., p. 884. 
Abdullah and the Haganah officers with Jordanian officers on the eve of the outbreak the 1948 war $^{17}$.

However, the most significant agreement between the two sides was signed on 28 November 1948, between the two commanders of Jerusalem: the Israeli Moshe Dayan and the Jordanian Abdullah al-Tall. In this agreement known as the "Sincere cease-fire", the commanders agreed to keep the truce in Jerusalem from 1 December on 6:00am and expand it to other areas in the entire Jerusalem area, according to a map that was drawn up and attached to it ${ }^{18}$.

The border dividing Jerusalem between the two countries was about seven kilometers long from Mount Scopus in northern Jerusalem, passing through the Old City, Abu Tur, Ramat Rachel and Beit Safafa in the south. The Mandelbaum Gate was one of the three demilitarized zones established along the border, but was the only one through which it was possible to cross to the Jordanian side and enter Jordan from Israel. The other two demilitarized zones were Mount Scopus in the north and the Government House in the south, which has been the seat of the United Nations observer headquarters in the Middle East to this day.

The move to the Jordanian side through the Mandelbaum Gate was one-way, because Jordan did not recognize the State of Israel and therefore did not allow people who came from Israel to return to it ${ }^{19}$. This policy was known to every Palestinian and was also reflected in the Palestinian stories that related to the Mandelbaum Gate. The Mandelbaum gate aroused great interest in Palestinian literature and this was reflected by writers who emphasized the moods and emotional implications of the existence of the gate on the daily life of the Palestinian residents in their writings.

In his story The Mandelbaum Gate (1954) ${ }^{20}$, the famous Palestinian writer Emile Habibi (1922-1996) ${ }^{21}$ describes his memories from the day he and his family were separated from his mother who was about to cross to the Jordanian side

${ }^{17}$ Deputy Head of the Political Department of the Jewish Agency Golda Myerson met twice with King Abdullah on 17 November 1947 and on 11 May 1948. The Haganah officers met with Jordanian officers on 2 May 1948. On the meetings see B. Morris, The Road to Ferusalem: Glubb Pasha, Palestine and the fews, London 2003, pp. 101-102.

${ }^{18}$ The agreement is known as "The Sincere Cease-Fire". For the full agreement see ISA 13.15/2; J.B. Glubb, A Soldier with the Arabs..., p. 216; M. Dayan, Story of My Life, Jerusalem 1976, p. 101.

${ }^{19} \mathrm{~K}$. Cohen-Hattab, The Border as Bridge..., p. 888.

${ }^{20}$ E. Habibi, Bawabat Mandelbaum, [in:] Al-A'mal al-Adabiyyah al-Kamilah, Nazareth 1997, pp. 19-29.

${ }^{21}$ Habibi was a writer, a journalist, a Knesset member and an Arab-Israeli activist. He was one of the founders of the Israeli Communist Party and served as its Knesset member for nineteen years. He also founded the al-Ittihad newspaper and served as its editor-in-chief. In the 1950s he began to write short stories and after his retirement from the Knesset wrote his famous novel The Optimist (Al-Mutasha'il, 1974). His literary writings have been translated into many languages and he has won awards for his work. 
of the Mandelbaum Gate to see her daughter across the border. The separation is described in the story as an eternal separation, according to the rules of the place, and it is clearly reflected in the words of the Israeli customs official, who tells the old mother who crosses the border: "Whoever comes out of here will never return" 22 .

Christian and Muslim tourists and pilgrims who travelled to the Hajj in Mecca also passed through the Mandelbaum Gate. Initially, movement was minimal, because Jordan forbade the entry of tourists from Israel. Israel also did not encourage the departure of Arab Muslims and Christians to the Jordanian side for fear that the Jordanian intelligence personnel would recruit them for espionage purposes against Israel. Therefore, most of the movement comprised Jordanian tourists who came to Israel ${ }^{23}$.

It seems that the free crossing of pilgrims and tourists from Israel to Jordan, and vice versa, did not find favor with the Palestinians. Emile Habibi reflects this in The Mandelbaum Gate. "The foreigners", he writes, "can eat lunch at the Philadelphia Hotel [in the Old city of Jerusalem] and in the evening at the Eden hotel [in the Hebrew Jerusalem] ${ }^{24}$, but Palestinians, are not allowed to do so.

In the same story Habibi also reflects and emphasizes the dichotomy created by the Mandelbaum Gate when he writes, "this square has two gates, the Gate here and the Gate there"25; "Every gate is suitable for the passage of an "outbound' or an 'inbound' car"”26; "Here we speak Hebrew and there is Arabic"27. In this way, Habibi actually describes two hostile states, which seem to have no connection.

However, Habibi, like other Palestinian residents, did not know that behind the scenes the relations between the two states were growing stronger. The diplomatic contacts between Israel and Jordan after the 1948 war, which were intended to bring about a peace agreement, disappeared in the eyes of the Palestinian residents, and therefore what they perceived to be the case only served to make life difficult for them ${ }^{28}$.

The contact between Israel and Jordan, intended to bring an end to the war, increased at the end of 1948. The first round of talks between the two countries were held at The Mandelbaum House, which stood between the Israeli side and the Jordanian side of Jerusalem. The two commanders, who met there on 3 January 1949 , were committed to resolving their dispute peacefully ${ }^{29}$. One of the

${ }^{22}$ E. Habibi, Bawabat Mandelbaum..., p. 21.

${ }^{23}$ K. Cohen-Hattab, The Border as Bridge..., p. 889.

${ }^{24}$ E. Habibi, Bawabat Mandelbaum..., p. 26.

${ }^{25}$ Ibidem, p. 21.

${ }^{26}$ Ibidem.

${ }^{27}$ Ibidem, p. 28.

${ }^{28}$ On 24 February 1950 Israel and Jordan signed the peace draft agreement, however, in the end it was not approved by the Jordanian government.

${ }^{29}$ A. al-Tall, Karithat Filastin..., p. 452; M. Dayan, Story of My Life..., p. 106. 
issues in dispute was the question of the Israeli prisoners in Jordan. By order of King Abdullah, all 679 Israeli prisoners from the POW camp in Jordan were released at the Mandelbaum Gate ${ }^{30}$.

The final armistice agreement of April 1949 determined that the Mandelbaum House would remain within the borders of the State of Israel. Due to its proximity to the Jordanian side and to it being the site of the two-week convoy to Mount Scopus and the seat of the United Nations Armistice Commission, the Israeli government decided to turn it into the only crossing point between the two countries in Jerusalem. It remained as such for 19 years, from 1948 to $1967^{31}$.

\section{Mandelbaum Gate as an Expression of Normalization between Israel and Jordan}

As history has shown, the hostilities between the two countries (terrorist attacks, security tensions, Israel's reprisals, etc.) did not prevent the two countries from working together to keep the Mandelbaum Gate operational. The two prominent commanders of the Gate were Baruch Mimran from Israel and Jabir Fatin (Abu Ahmad) from Jordan, who, together, managed to rise above politics. They held daily work meetings, as part of the desire to live together and normalize this area. Moreover, the UN established a base near the Mandelbaum Gate, in order to allow the armistice commission to meet under its supervision and discuss the problems of the armistice agreement. Although it divided Jerusalem formally between Jordan and Israel, the checkpoint continued to constitute a place of relative normalization between two states which had hitherto failed to reach a peace agreement despite the efforts that were invested during the years 1949-1950.

The establishment of the border crossing was not part of the armistice agreement between the two countries. Rather, it served the vital needs of the Palestinian residents to meet their families or to move to Jordan for personal, religious and political reasons. This is reflected in the story The Mandelbaum Gate (1963) by the Nazareth-born writer Najwa Qawar (1920-2015), who was considered one of the most prominent writers of that period ${ }^{32}$. The story describes the Gate as a meeting point and as a point of union between Palestinian families. It is a "world of meeting" ${ }^{33}$, a place of sanctuary which carries within

\footnotetext{
${ }^{30}$ A. al-Tall, Karithat Filastin..., pp. 404-405.

${ }^{31} \mathrm{~K}$. Cohen-Hattab, The Border as Bridge..., p. 883.

${ }^{32}$ Qawar was active in the radio, television, and press. She and her husband founded al-Ra'id newspaper and published political, social and literary articles. She lived in Haifa until 1960 and then lived in Jerusalem, Ramallah, Beirut and London. In her final years she lived in Toronto. Qawar wrote numerous collections of short stories, novels and poetry.

${ }^{33}$ N. Qawar, Bawabat Mandelbaum, [in:] li-man al-Rabi', Nazareth 1963, p. 59.
} 
it the possibility of meeting, learning, and keeping abreast of what is happening on the other side of the Gate. The Gate in this story is depicted not only as a meeting place for family members who come from the Jordanian side, but also as a meeting place for the residents themselves. Everyone there is surrounded by a sense of excitement, curiosity and joy. The Gate is described as a center of attraction and focal point for pilgrims and those who were otherwise unable to meet their loved ones.

The Mandelbaum Gate also had a humanitarian role. It was used to return civilians who had crossed by mistake or to transfer patients from Jordan to hospitals in Israel. In his story The Mandelbaum Gate, Emile Habibi also noted this humanitarian aspect of the Gate. When the daughter of the narrator accidentally crosses to the Jordanian side together with her Grandmother, the policemen on both sides look on awkwardly as she hastily returns to Israel unharmed. "What a wonderful thing", writes Habibi. "A girl crosses the "Valley of Death' [Mandelbaum Gate], which has no return and returns from it after it violated the reality of the war, the border and the Mandelbaum Gate" 34 .

The Gate also symbolized the Israeli longing for a normalization of the relationship with the Jordanian side. Since the Gate was open all year round, including Saturdays, due to its proximity to the ultra-Orthodox neighborhoods of Jerusalem, there were often demonstrations and denunciations of tourists who used the crossing on Saturdays ${ }^{35}$. The police dispersed the demonstrations and ensured the safe passage of the tourists. The ultra-Orthodox parties also put pressure on Prime Minister Levi Eshkol to close the Gate, but he rejected their pleas and ordered that it remained open on Saturdays and the holidays, because of the agreement with the Jordanian government.

Israel's desire to present a degree of normalization at the Gate gave rise to optimism for cooperation between the two countries on other issues as well as for the signing of a peace agreement between them. Hope and optimism also exist in the story The Mandelbaum Gate by Qawar. Qawar stresses the elderly mother's hope of meeting her family. The mother reminisces about the past and marches ineffectually toward the Gate. The memories of the past that emerge in the old woman's mind, seem at first to be a kind of excitement prior to the meeting. However, it soon becomes clear that these memories are an attempt to create hope, since in fact "three years have passed since that day, and every year she would register to cross and was not given permission. She stood like she did now, watching the joyous people and living the emotions of her past" ${ }^{\prime 6}$. The story expresses despair on the one hand, but also shows that the old woman has not lost hope entirely. This hope manifests itself at the end of the

\footnotetext{
${ }^{34}$ E. Habibi, Bawabat Mandelbaum..., p. 26.

${ }^{35}$ K. Cohen-Hattab, The Border as Bridge..., pp. 893-894.

${ }^{36} \mathrm{~N}$ Qawar, Bawabat Mandelbaum..., pp. 64-65.
} 
story, when the old woman "moved her head and continued walking (...) Continued to walk toward the cars while continuing to run away from herself and imagine the meeting that never took place" ${ }^{37}$. Although her neighbors believed that she had gone mad, and that marching would take her nowhere, from the old woman's point of view, it was the only concrete thing left for her to do that might keep her hope alive.

\section{Conclusion and Epilogue}

This paper has presented the story of the Mandelbaum Gate - the only border crossing between Israel and Jordan which operated during the division of Jerusalem between 1948 and 1967. The Mandelbaum Gate was not only a crossing point from Israel to Jordan and vice versa, but it also provided an outward display of the secret relations which existed between the two countries.

On the face of it, relations between the two countries seemed hostile as was clearly reflected, as we have seen, in some or in parts of the Palestinian literary works that appeared at the time. However, in reality, behind the scenes, the relations were warm to the point of reaching a peace agreement between the countries. This was also reflected in other parts or in other literary works of the period, which described the Gate also as a central meeting point for Palestinian families who otherwise would not have been able to meet. These writers described the humanitarian role of the Gate and its significance as a source of hope and optimism.

Later, this idyllic and unique space turned out to be a temporary illusion. When the Six-Day War broke out in June 1967, the Armistice Commission tried to calm the tension between the two countries, but failed. King Hussein did not respond to the American or to the United Nations requests and decided to join Egypt and Syria in the war. Israel quickly took control of the Gate on the second day of the war and captured the Jordanian troops. Two months later, in August 1967, as part of the unification of Jerusalem (East and West), the Jerusalem municipality removed the ruins of the building and the remains of the Mandelbaum Gate disappeared completely. The building that served the Jordanian side was also destroyed, and only the UN base, where meetings of the Armistice Commission were held, remains in place today.

${ }^{37}$ Ibidem, p. 65. 